\title{
Leishmania in synanthropic rodents (Rattus rattus): new evidence for the urbanization of Leishmania (Leishmania) amazonensis
}

\section{Leishmania em roedores sinantrópicos (Rattus rattus): uma nova evidência da urbanização de Leishmania (Leishmania) amazonensis}

\author{
Eloiza Teles Caldart ${ }^{1,2 *}$; Roberta Lemos Freire ${ }^{1}$; Fernanda Pinto Ferreira ${ }^{1}$; Bruno Bergamo Ruffolo ${ }^{1}$; \\ Mônica Raquel Sbeghen³; Marcelle Mareze'; João Luis Garcia²; Regina Mitsuka-Breganó2; \\ Italmar Teodorico Navarro ${ }^{1}$
}

\begin{abstract}
${ }^{1}$ Laboratório de Zoonoses e Saúde Pública, Departamento de Medicina Veterinária Preventiva, Universidade Estadual de Londrina UEL, Londrina, PR, Brasil

${ }^{2}$ Laboratório de Parasitologia, Departamento de Medicina Veterinária Preventiva, Universidade Estadual de Londrina - UEL, Londrina, PR, Brasil

${ }^{3}$ Laboratório de Imunologia Animal, Departamento de Ciências Patológicas, Universidade Estadual de Londrina - UEL, Londrina, PR, Brasil
\end{abstract}

Received August 30, 2016

Accepted October 25, 2016

\begin{abstract}
This study aimed to detect parasites from Leishmania genus, to determine the prevalence of anti-Leishmania spp. antibodies, to identify circulating species of the parasite, and to determine epidemiological variables associated with infection in rats caught in urban area of Londrina, Paraná, Brazil. Animal capture was carried out from May to December 2006, serological and molecular methods were performed. DNA was extracted from total blood, and nested-PCR, targeting SSu rRNA from Leishmania genus, was performed in triplicate. The positive samples were sequenced twice by Sanger method to species determination. In total, 181 rodents were captured, all were identified as Rattus rattus and none showed clinical alterations. Forty-one of the $176(23.3 \%)$ animals were positive for Leishmania by ELISA and 6/181 (3.3\%) were positive by IFAT. Nine of 127 tested animals $(7.1 \%)$ were positive by PCR; seven were identified as $L$. $(L$.) amazonensis, one as $L$. $(L$.) infantum. Four rats were positive using more than one test. This was the first description of synanthropic rodents naturally infected by $L$. (L.) amazonensis (in the world) and by $L$. (L.) infantum (in South Brazil). Regarding $L$. (L.) amazonensis, this finding provides new evidence of the urbanization of this etiological agent.
\end{abstract}

Keywords: Leishmaniasis, Londrina, PCR, zoonosis, Leishmania (L.) infantum, Leishmania (L.) amazonensis.

\section{Resumo}

Esse estudo objetivou detectar parasitos do gênero Leishmania, determinar a prevalência de anticorpos anti-Leishmania spp., identificar as espécies circulantes do parasito e determinar variáveis epidemiológicas associadas com a infecção em ratos capturados em área urbana de Londrina, Paraná, Brazil. A captura dos animais ocorreu de maio a dezembro de 2006, métodos sorológicos e moleculares foram realizados. O DNA foi extraído do sangue total, uma nested-PCR cujo alvo foi o gene SSu rRNA do gênero Leishmania, foi realizado em triplicata. As amostras positivas foram sequenciadas duas vezes pelo método de Sanger para a determinação da espécie. No total, 181 roedores foram capturados, todos foram identificados como Rattus rattus e nenhum apresentou alteraçôes clínicas. Quarenta e um dos 176 (23,3\%) animais foram positivos no ELISA para Leishmania e 6/181 (3,3\%) foram positivos na RIFI. Nove dos 127 animais testados $(7,1 \%)$ foram positivos na PCR; sete foram identificadas como L. (L.) amazonensis, um como L. (L.) infantum. Quatro ratos foram positivos em mais de um teste. Essa é a primeira descrição de roedores sinantrópicos naturalmente infectados por L. (L.) amazonensis (no mundo) e por L. (L.) infantum (no Sul do Brasil). Com relaçáo a L. (L.) amazonensis, esse resultado é uma nova evidência da urbanização desse agente etiológico.

Palavras-chave: Leishmanioses, Londrina, PCR, zoonoses, Leishmania (L.) infantum, Leishmania (L.) amazonensis.

*Corresponding author: Eloiza Teles Caldart. Laboratório de Zoonoses e

Saúde Pública, Departamento de Medicina Veterinária Preventiva, Universidade

Estadual de Londrina - UEL, Rodovia Celso Garcia Cid, 445, Km 380,

CEP 86057-970, Londrina, PR, Brasil. e-mail: eloiza.vet@gmail.com 


\section{Introduction}

The Leishmania parasite is a member of the Kinetoplastida class and Trypanosomatidae family, which comprises species that infect multiple mammalian species (GRAMICCIA, 2011; ROQUE \& JANSEN, 2014). In nature, all species of this genus are transmitted to the vertebrate host by the bite of hematophagous females of several species of phlebotomine sand flies (class: Insecta, order: Diptera) (FORATTINI, 1973). These protozoan species have complex transmission cycles with region-specific epidemiological characteristics (ASHFORD, 1996; ROTUREAU, 2006). Infections by the aforementioned parasites can lead to diseases with a wide spectrum of clinical forms; these are collectively known as leishmaniosis, which are zoonosis and neglected infectious diseases (DUJARDIN et al., 2008; ALVAR et al., 2012).

Approximately 58,000 cases of visceral leishmaniosis (VL) are reported worldwide each year and six countries together account for more than $90 \%$ of the global estimated VL incidence: India, Bangladesh, Sudan, South Sudan, Ethiopia, and Brazil (ALVAR et al., 2012). Between 2007 and 2015, 33,488 VL human cases were notified in Brazil and the mortality rate was 6.36\% (SINAN, 2016). VL is caused by Leishmania (Leishmania) infantum (also known as $L$. (L.) chagasi), and its vectors are Lutzomyia longipalpis and Lutzomyia cruzi, the second being of limited importance (BRASIL, 2014). In the 1990 s, approximately $90 \%$ of reported Brazilian $\mathrm{VL}$ cases occurred in the northeast region. However, this trend appears to be changing, as the disease reaches urban and peri-urban areas of all regions of the country (BRASIL, 2014). VL was not considered endemic to Paraná State until July 15, 2015, when the first autochthonous human case was reported (ANP, 2015).

Regarding cutaneous leishmaniosis (CL), 220,000 cases are reported each year worldwide and ten countries together account for 70 to $75 \%$ of its global estimated incidence; Brazil is also included in this list (ALVAR et al., 2012). The American cutaneous leishmaniosis (ACL) in Brazil represents a serious public health problem; it has been diagnosed in all states since 2003 (BRASIL, 2013). Between 2007 and 2015, 0.45\% of human ACL cases in Brazil have occurred in the southern region, with Paraná State accounting for 57.2 to $98.0 \%$ (PONTELLO et al., 2013; SINAN, 2016). Autochthonous cases in dogs have been reported in Paraná state (CASTRO et al., 2007). The primary reservoirs of ACL disease-causing agents are small mammals, particularly wild rodents (BRANDĀO-FILHO et al., 2003; DANTAS-TORRES et al., 2010; ROQUE \& JANSEN, 2014). Although ACL maintains a rural disease profile, its occurrence can also be found in urban areas; this is especially true with remaining forest or vegetation corridors associated with the local hydrography, and with primary and secondary riparian forests (NEGRÃO \& FERREIRA, 2009; MEMBRIVE et al., 2012; CONSTANTINO et al., 2014).

Rattus rattus also known as roof rat is the predominant rodent in mostly rural areas of Brazil and it is also common in urban centers. These animals tend to live on high surfaces, and travel down to ground level in search of food and water. They live in groups, the size of which depends on existing resources (FUNASA, 2002; BONVICINO et al., 2008). The black rat is an exotic species introduced to the Americas during the colonization period, and has been suspected to serve as a reservoir for Leishmania (Viannia) braziliensis complex in Brazil (ROQUE \& JANSEN, 2014); these animals are also potential sources of infection to peri domestic sandflies (BRANDÁO-FILHO et al., 2003). The production of huge quantities of waste, the reduction of areas available for disposal of these materials, and urbanization processes are examples of human actions that occur in many cities in Brazil and other countries. These activities create environments conducive to the spread of leishmaniosis as they increase the range and density of vectors and reservoirs.

The magnitude of health problems caused by leishmaniosis, combined with the complexity of its epidemiology, indicate a need to understand all stages in its transmission and develop effective control strategies (ROQUE \& JANSEN, 2014). Solid waste recycling centers, investigated herein, offer environmental complexity and all relevant aspects for the study of Leishmania; this study aimed to investigate infections by Leishmania spp., identify circulating species of the parasite, and to determine epidemiological variables associated with infection in urban rats.

\section{Methods}

\section{Location of study}

The city of Londrina $\left(23^{\circ} 18^{\prime} 36^{\prime \prime S} / 51^{\circ} 09^{\prime} 46^{\prime \prime} \mathrm{W}\right)$ is located in the north-central mesoregion of Paraná State, in the southern region of Brazil. It is $610 \mathrm{~m}$ above sea level and has a subtropical climate, with year-round rainfall concentrated mostly in the summer months. It has an average annual temperature above $21^{\circ} \mathrm{C}$ and an estimated human population of 543,003 (IBGE, 2015).

\section{Sampling}

The points for collection of data and animals were the recycling centers of solid waste and junkyards from the five regions of the city; a starting point was taken as the surroundings of Basic Health Units (BHU). The sample size calculation was done using EpiInfo 3.5.3 (DEAN et al., 1990), for an infinite population; a prevalence of $50 \%$ was estimated, with a precision of $7.5 \%$ and a significance level of 5\%, resulting in 171 samples. The work was designed to search for more than one parasite species; how we couldn't choose just one prevalence value, we have chosen $50 \%$, because it gives us the larger possible number of samples taking into account the other given fixed parameters (precision, confidence level and population size).

\section{Animal trapping and sample collection}

The rats were captured between the months May and December 2006, using cage mousetraps where the trigger is activated by bait placed in its interior. Traps were assembled at the end of the afternoon in areas where we found traces of rodents such as feces, fat stains, trails, or areas of plentiful food; we checked the traps the following morning. Rats were captured, identified by Prof. DSc Roberta Lemos Freire, and anesthetized for the collection of blood 
and serum from the brachial plexus. After which, animals were euthanized. Half of the material was kept at room temperature until the clot reaction occurred (to obtain the serum), whereas the other half was taken for whole blood and frozen at $-20{ }^{\circ} \mathrm{C}$ until use.

\section{ELISA}

The number of samples analyzed by each method varied according to the availability of the collected material. Serum samples were analyzed, in duplicate, by ELISA (enzyme linked immunosorbent assay) to determine the prevalence of anti-Leishmania spp. IgG antibodies as recommended by the Ministério da Saúde (MS) for screening the canine population. Antigen preparation and ELISA were performed according to Szargiki (2005) with minor modifications. In each well of the ELISA plates (Microlon 600, Greiner), $100 \mu \mathrm{L}$ of L. (L.) amazonensis (MCAN/BR/2011/cãoLV01) total promastigote lysate $(2.5 \mu \mathrm{g} / \mathrm{mL})$, previously diluted in sodium carbonate-bicarbonate buffer $(0.05 \mathrm{M}, \mathrm{pH}$ 9.6), was added. After overnight incubation at $4{ }^{\circ} \mathrm{C}$, plates were washed three times with $0.9 \%$ saline containing $0.05 \%$ Tween-20, and were blocked for $1 \mathrm{~h}$ at $37^{\circ} \mathrm{C}$ using $200 \mu \mathrm{L}$ of $2 \%$ casein in phosphate buffered saline containing 0.05\% Tween-20 (PBS-Tween 20). After another wash, $100 \mu \mathrm{L}$ of sera diluted (1:50) in PBS-Tween 20 was added to each well and incubated for $1 \mathrm{~h}$ at $37^{\circ} \mathrm{C}$. After another wash, $100 \mu \mathrm{L}$ of anti-Rat IgG labeled with peroxidase (Sigma Aldrich - A9037) was added to each well and incubated for $1 \mathrm{~h}$ at $37^{\circ} \mathrm{C}$. The enzyme reaction was carried out with $100 \mu \mathrm{L}$ of o-Phenylenediamine dihydrochloride (Sigma Aldrich - P8287) solution according to the manufacturer's instructions. The reaction was stopped by adding $50 \mu \mathrm{L}$ of $1 \mathrm{M} \mathrm{H}_{2} \mathrm{SO}_{4}$, and the optical density (OD) was read at $450 \mathrm{~nm}$ using an ELISA reader (iMark, Bio-Rad). Six negative and four positive controls were included in each plate, in duplicate, and values were expressed as the mean $\mathrm{OD}$ of the serum. The mean $\mathrm{OD}$ value from negative controls plus three standard deviations was considered as the cut-off point. The negative control was obtained from a young laboratory black rat, and the positive controls were from the research group of Prof. DSc. Mario Augusto Ono.

\section{IFAT}

Serum samples were analyzed by IFAT (immunofluorescence antibody test) according to Oliveira et al. (2008) to determine the prevalence of anti-Leishmania spp. IgG antibodies as recommended by the Ministério da Saúde (MS) for confirmation in canine populations. IFAT slides were prepared using Leishmania (Leishmania) amazonensis (MCAN/BR/2011/cãoLV01) promastigotes (OLIVEIRA et al., 2008). The concentration of anti-Rat IgG FITC (Sigma Aldrich - F6258) conjugates was standardized for the slides. Positive and negative controls were included in all tests; the negative control was obtained from a young black laboratory rat, and the positive control was from the research group of Prof. DSc. Mario Augusto Ono. In positive serum samples, parasites displayed a bright-green peripheral stain and the considered cutoff point was a titer of 20 (BEN-ISMAIL et al., 1989; CÁSSIA-PIRES et al., 2014).
Positive samples were serially diluted two-fold to obtain a bigger reagent titer.

\section{$D N A$ extraction}

The DNA extraction was performed from whole blood of synanthropic rodents using the commercial QIAmp DNA Blood Mini Kit (Qiagen), according to the manufacturer's recommendations. Negative controls for the DNA extraction process were used in all assays, included for every ten samples, and were tested with the samples to identify possible contamination of samples during the DNA extraction procedure. The extracted DNA was eluted with $50 \mu \mathrm{L}$ of elution buffer in a sterile $1.5 \mathrm{~mL}$ tube, identified for use in PCR reactions, and stored at $-20^{\circ} \mathrm{C}$. The DNA extraction yield was determined by measuring the absorbance at $260 \mathrm{~nm}$ in a Picodrop (Thermo Fisher Scientific, Wilmington, DE, USA) spectrophotometer and the A260/A280 absorbance ratio was assessed to verify the purity of the obtained DNA.

\section{Molecular detection}

To detect Leishmania parasites, we utilized a nested-PCR (nPCR) assay targeting the small subunit of ribosomal RNA (SSu RNAr) gene fragment, which is within a region that is highly conserved among Leishmania species. The first amplification step was performed with $2 \mu \mathrm{L}$ of DNA solution added to $23 \mu \mathrm{L}$ of PCR mix containing $0.2 \mathrm{mM}$ deoxynucleoside triphosphates (Amersham Pharmacia Biotech, Sweden), 2 mM MgCl, $5 \mathrm{mM} \mathrm{KCl,} 75 \mathrm{mM}$ Tris- $\mathrm{HCl}$, pH 9, 1 U Platinum Taq DNA Polymerase (Life Technologies) and 20 pmol of specific primers (R221 and R332) (VAN EYS et al., 1992). The amplification conditions were denaturation at $94^{\circ} \mathrm{C}$ for $5 \mathrm{~min}$, followed by 30 cycles of $30 \mathrm{~s}$ at $94{ }^{\circ} \mathrm{C}, 60{ }^{\circ} \mathrm{C}$, and $72{ }^{\circ} \mathrm{C}$, and a final extension at $72{ }^{\circ} \mathrm{C}$ for $5 \mathrm{~min}$. Two microliters of the resulting amplification product was used as a template in the second reaction in the presence of Leishmania genus specific primers (R223 and R333) (VAN EYS et al., 1992). The reaction conditions were the same as before except for an increased annealing temperature of $65^{\circ} \mathrm{C}$. The final reaction resulted in a $353 \mathrm{bp}$ fragment that was visualized after electrophoresis on $1.5 \%$ agarose gel (Invitrogen) stained with SyBr safe DNA stain (Invitrogen). Every set of reactions included a PCR-negative control (ultrapure water), an nPCR-negative control (ultrapure water), and a positive control (L. (L.) infantum MHOM/BR/75/M2903DNA or L. (L.) amazonensis MCAN/BR/2011/cãoLV01). All samples were tested in triplicate to improve sensitivity, as we were using DNA extracted from total blood as a template.

\section{Parasite species characterization}

The SSu rRNA PCR products were purified using a QIAquick PCR Purification kit (QIAGEN), and quantified using a Picodrop (Thermo Fisher Scientific, Wilmington, DE, USA). Direct Sanger sequencing was performed using the BigDye Terminator v.3.1 Cycle Sequencing kit (Applied Biosystems, Carlsbad, USA) with the corresponding forward and reverse primers, in the 3500 Genetic Analyzer (Applied Biosystems, Carlsbad, USA), according to the 
manufacturer's instructions. The obtained sequences were examined with PHRED software (EMBRAPA, 2016) for quality analysis of chromatogram readings. The sequences were accepted if base quality was equal to or higher than 20. Consensus sequences were determined by CAP3 software (EMBRAPA, 2016) and the sequence identity was verified by comparison to sequences deposited in GenBank using BLAST software (NCBI, 2016).

To distinguish $L$. (L.) amazonensis from $L$. (L.) mexicana we performed another PCR using extracted DNA from positive rats in SSU rRNA PCR. Polymorphism-specific primers (a1: 5'-TGCGAGGATAAAGGGAAAGAA-3' and a2: 5'-GTGCCCTGACTTGCATGTCTA-3') targeting the $\mathrm{p} 53$ gene were used according to Mimori et al. (1998). These primers amplify L. (L.) amazonensis and do not amplify $L$. (L.) mexicana because of a difference between these two species in the $3^{\prime}$ region of primer a1. If $L$. (L.) amazonensis is present, the PCR will result in a $62 \mathrm{bp}$ fragment, if not the PCR is going to be negative.

\section{Research tools}

To obtain epidemiological data concerning parameters such as environment, sanity, species, age, and gender a questionnaire was used; the association of these factors was later made with the obtained results.

\section{Statistical analysis}

Data tabulation was performed using EpiInfo 3.5.3 (CDC, Atlanta). Statistical significance between questionnaire variables and leishmanosis were evaluated by chi-square (x2) or Fisher's exact tests with a $5.0 \%$ significance level.

\section{Nucleotide sequence data}

Nucleotide sequence data reported in this paper are available in the GenBank database under the accession numbers: KX011478, KX011479, KX011480, KX011481, KX011482, KX011483, KX011484, KX011485.

\section{Ethical considerations}

This study was approved by the Comitê de Ética em Experimentação Animal (CEEA) of the Universidade Estadual de Londrina (no 28/2006).

\section{Results}

A total of 181 rodents were captured, and all of them were identified as Rattus rattus species; 104/181 (57.5\%) were female and $150 / 181(82.9 \%)$ were adults. The animals were apparently healthy and showed no visible ectoparasites upon visual inspection. These animals were captured at 35/35 collection sites (100\%), distributed in north (7), south (6), east (6), west (7), and central (9) regions of Londrina city. The region with the highest number of captured rats was the central with $62 / 181$ catches $(34.3 \%)$.
Owners or workers of all sites visited reported the presence of rats at night and at any establishment we found workers using of personal protective equipment (PPE). Dogs lived at 29/35 capture sites (82.8\%), cats at $2 / 35(5.7 \%)$, and chickens at $2 / 35(5.7 \%)$.

Regarding serological testing of rats, 41/176 (23.3\%) were positive by ELISA, but only two samples showed expressive OD; the others were very close to the cutoff point. Of the 41 positives, $28(68.3 \%)$ were female and $39(95.1 \%)$ were adults. Data analysis revealed an association between Leishmania positivity (by ELISA) and age ( $\mathrm{p}=0.027)$; a higher proportion of adult animals were positive than young animals. Using IFAT, 6/181 (3.3\%) rats were positive; two had a titer equal to 20 , three had a titer equal to 40 and one had a titer equal to 80 . All positive were female and adult. Data analysis revealed an association between IFAT positivity in rats and the free access of other animal species in the places of rodent collection $(p=0.032)$. From 127 rats analyzed by molecular methods, nine $(7.1 \%)$ were positive by SSU rRNA PCR. Three of nine positive rats were captured at the same address (Figure 1). Of the nine positive, six (66.7\%) were female and six (66.7\%) were adults. PCR data analysis revealed no association between leishmaniosis in rats and all other variables tested. Considering all diagnosis methods used in this study, we had 51 positive animals, three rats were positive in two tests, one was positive using all methods. In this population, the positive proportion of female rats was higher than that of male rats when considering all three diagnostic methods ( $\mathrm{p}=0.038)$. The $353 \mathrm{bp}$ fragments from SSu rRNA PCR, from the nine positive animals, were purified and sequenced twice by the Sanger method; seven samples were identified as $L$. (L.) amazonensis or $L$. (L.) mexicana, and one was identified as $L$. (L.) infantum (Figure 2); one could not be sequenced. We further confirmed $L$. (L.) amazonensis detected samples by performing a1/a2 polymorphism-specific PCR (PS-PCR) described by Mimori et al. (1998).

\section{Discussion}

The high prevalence of rodents, captured in solid waste recycling sites, indicates the existence of shelter, food and water, essential components for habitation and proliferation of rodents. The dispersion of the species $R$. rattus is $50 \mathrm{~m}$ (FUNASA, 2002), which is indeed worrisome as 15 of the 35 sites selected for this study contained residences. Any animal caught in this study presented no signs of disease, based on clinical examination, which was also reported in previous studies (OLIVEIRA et al., 2005; AKHAVAN et al., 2010; MARCELINO et al., 2011; LIMA et al., 2013).

Regarding serological methods, we determined 41/176 (23.3\%) of animals to be positive by ELISA and 6/181 (3.3\%) by IFAT. The literature is scarce regarding serological diagnosis of leishmaniosis in rats; we could only find two studies using an immunochromatographic method (LIMA et al., 2013; SINGH et al., 2013), two using ELISA (MUKHTAR et al., 2000; BARBOSA, 2005) in Sudan and Brazil, and two using IFAT (BEN-ISMAIL et al., 1989; CÁSSIA-PIRES et al., 2014) in Tunisia and Brazil. Our prevalence based on ELISA was higher (23.3\%) than previously reported ( $0 \%$ in Brazil and $4.1 \%$ in Sudan) and based 


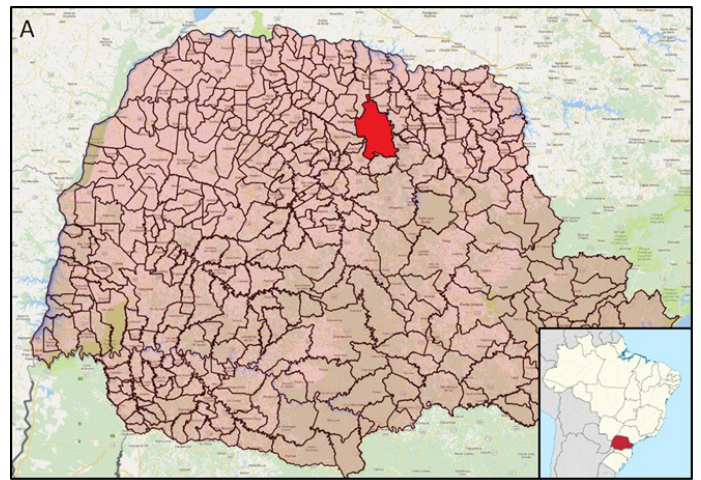

Legend:

$\begin{array}{ll}\text { North region } & \Delta \text { Rat IFAT+ } \\ \text { West region } & \bigcirc \text { Rat ELISA + } \\ \text { East region } & \square \text { Rat PCR+ } \\ \text { Central region } & \text { Dog IFAT }+ \\ \text { South region } & \end{array}$
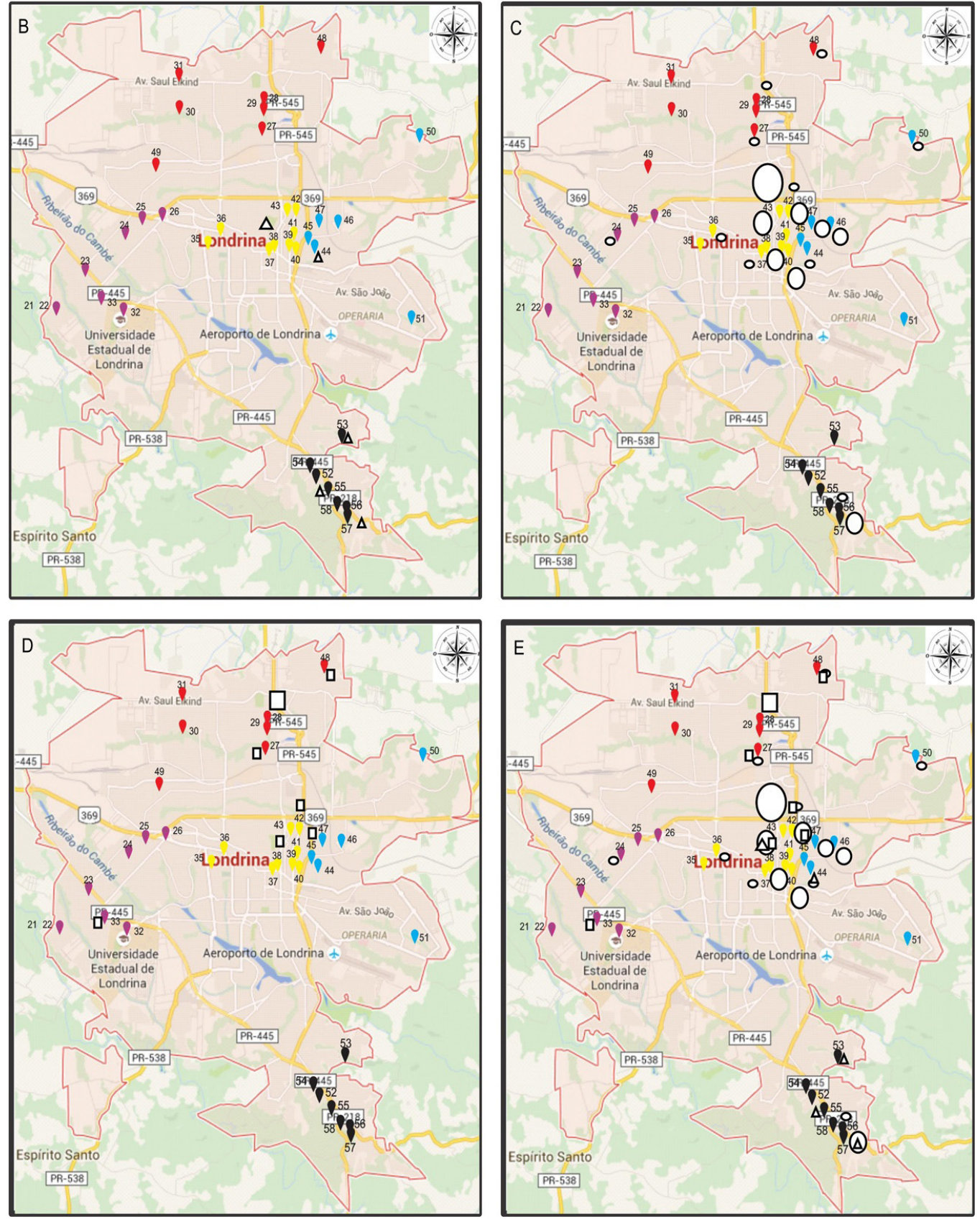

Figure 1. (A) Geographic localization of Londrina city in Paraná State and in Brazil; (B) Geographic distribution of collection sites and positive rats determined by IFAT; (C) Geographic distribution of collection sites and positive rats determined by ELISA; (D) Geographic distribution of collection sites and positive rats determined by PCR; (E) Geographic distribution of collection sites and positive rats determined by IFAT, ELISA, and PCR. The sizes of the circles, triangles, and rectangles represent the number of positive rats at each collection point. 


\begin{tabular}{|c|c|c|c|c|c|c|c|}
\hline & & 10 & 20 & 30 & 40 & 50 & 60 \\
\hline & & 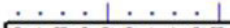 & 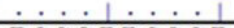 & $\ldots .1$. & 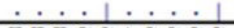 & & \\
\hline L.braziliensis & 1 & CATCGCAACT & T CGG T T CGG T & G T G T G G C G C C & T T T GGAGGGG & T T T A G T G G T & C C G G T C GGG \\
\hline L.amazonensis & 1 & CATCGCAACT & T CGGT T CGGT & G T G T G G C G C C & T T T GGAGGGG & T T T A T T C G T & C CGGTGCG \\
\hline Rr 26 & 1 & C A T CG CA A C T & T CGG T T CGG T & G T G T G G C G C C & T T T G A G G G & T T T A T G C G T & C CGGT G C A A \\
\hline $\operatorname{Rr} 50$ & 1 & CA T CGCAACT & T CGG T T CGG T & G T G T G G C G C C & T T TGGAGGGG & T T T A T T CG T & C CGG T G CGAG \\
\hline Rr 63 & 1 & C A T CG CA A T & T CGGT T CGGT & G T G T G G C C C & T T T GGAGGGG & T T T A G T G C G T & C CGG T G C A A \\
\hline Rr 68 & 1 & C A T C G CA C T & T CGG T T CG T & G T G T G G C G C C & T T T G A GGGG & T T T A T T G G T & C CG T G C A A \\
\hline $\operatorname{Rr} 76$ & 1 & C A T CG CAA C T & T CGG T T CGG T & G T G T G G C G C C & T T T GGAGGGG & T T T A T G C T T & C CGG T G C G A \\
\hline Rr 103 & 1 & CA T CGCAACT & T CGGT T CGGT & G T G T G G C G C C & T T T GGAGGGG & T T T A G T G C T T & C CGGTGCGAG \\
\hline Rr 155 & 1 & C A T CG CA A C T & T CGG T T CGG T & G T G T G G C G C C & T T T GGAGGGG & T T T A G T C G T & C C G T T C G A G \\
\hline L.infantum & 1 & CA T CGCAACC & T C G T T C GG T & G T G T G G C G C C & T T T G A G G G G & T T T A T T C G T & C C G G TA G A G \\
\hline $\operatorname{Rr} 58$ & 1 & C A T C G CA A C C & T C GG T T CGG T & G T G T G G C G C C & T T T G $A$ G G G & T T T A G T C G T & C C G T $\mathrm{A} C \mathrm{C} \mathrm{G}$ \\
\hline
\end{tabular}

Figure 2. Partial alignment of nucleotides from SSu RNAr fragment of Leishmania spp. DNA from positive samples of $R$. rattus (Rr26, Rr50, $\operatorname{Rr} 58, \operatorname{Rr} 63$, Rr68, Rr76, Rr103, and Rr155) compared to L. (L.) amazonensis (M80293), L. (L.) infantum (M81430) and L. (V.) braziliensis (M80292) reference strains. Polymorphisms in positions 10, 35, and 56 differentiate L. (L.) infantum from L. (L.) amazonensis and L. (V.) braziliensis. Polymorphism in position 59 differentiates L. (L.) amazonensis from L. (V.) braziliensis.

on IFAT was lower (3.3\%) than that of previous reports $(27.2 \%$ in Tunisia and $51.3 \%$ in Brazil). The PCR prevalence was nine of 127 animals (7.1\%), which is a low prevalence upon comparing to other studies performed in Brazil (BRANDÁO-FILHO et al., 2003; OLIVEIRA et al., 2005; QUARESMA et al., 2011; LIMA et al., 2013; CARDOSO et al., 2015; FERREIRA et al., 2015), South America (ALEXANDER et al., 1998; LIMA et al., 2002), Iran (AKHAVAN et al., 2010; DAVAMI et al., 2013; MIRZAEI et al, 2014), Saudi Arabia (IBRAHIM et al., 1992), Italy (ZANET et al., 2014), Spain (NAVEA-PÉREZ et al., 2015), and Portugal (HELHAZAR et al., 2013). This low prevalence in PCR could be explained by our use of total blood as sample; most other studies used both blood and tissue (liver, spleen, skin, bone marrow). In few cases, the positivity rate of blood samples was higher than that of tissues (OLIVEIRA et al., 2005; MARCELINO et al., 2011). Neitzke-Abreu et al. (2013) tested the accuracy of some PCR-based techniques for CL diagnosis in humans and concluded that the use of blood (buffy coat) may be indicated for patients with no lesions. Our prevalence was higher than reported in other Brazilian (CÁSSIA-PIRES et al., 2014; LARA-SILVA et al., 2014) and foreign studies (LIMA et al., 2002; PAPADOGIANNAKIS et al., 2010; MENDONÇA et al., 2011; SHENDER et al., 2014; VLADIMIR et al., 2015). One study analyzed rodents from waste sites (VLADIMIR et al., 2015) in Croatia; $1 / 173(0.5 \%)$ rodent $(R$. rattus) tested positive for $L$. (L.) infantum; the authors identified five species of phlebotomine sand flies at those places.

Cássia-Pires et al. (2014) demonstrated infection rates of $51.3 \%$, using IFAT, and suggest that natural Leishmania infection is much higher than that observed using molecular diagnosis (4.6\%). In contrast, Lima et al. (2013), through serological testing, revealed an overall positivity of $5.0 \%$, whereas PCR yielded $28.6 \%$ positivity, and all seropositive animals were PCR negative. Regarding this lack of concordance between diagnostic methods, serological reacting samples thought to be from animals previously exposed to Leishmania parasites and are expected to be still infected. However, parasites have non-uniform distribution in tissues and blood of vertebrate hosts, and may not be present in analyzed tissues, resulting in a false negative through PCR. Furthermore, positive animals based on molecular diagnostics, but negative based on serology, may have been caught in an initial phase of infection before the production of detectable IgG, required for serological tests. Alternatively, it is crucial to take into account that the presence of other trypanosomatids was previously shown to lead to cross-reactions (DÍAZ-SÁEZ et al., 2014).

In the present work, five of nine positive animals by PCR were from the north region of Londrina city, three of them from the same address (collection point 28). At collection point 48 (north region), Costa et al. (2016) discovered a dog positive for leishmaniosis by IFAT and we discovered a PCR positive rat (Figure 1). This was a region with higher geographic expansion with a large number of illegally occupied areas in 2006 (IPPUL, 2008), the year of sample collection. This factor may explain why those animals had recent infections. The overall positivity, including that based on serological methods, was concentrated in the east $(42.3 \%)$ and central (35.4\%) regions. Although these collection points were in different regions, they were very close (Figure 1). At collection point 38 (central region) we had two rats test positive only by ELISA, one was positive by IFAT and ELISA, one was positive by ELISA, IFAT, and PCR, and another dog was positive by IFAT (COSTA et al., 2016); this demonstrates a trend that Leishmania detection had hot spots in Londrina city (Figure 1).

This study demonstrated statistically more adult animals positive through ELISA than young animals in the rodent population. These findings are likely explained by increased exposure to infected vectors throughout the rats' lives. Data analysis revealed a statistical association between IFAT positivity in rats and places where other animal species were not allowed to enter, for example, dogs, cats and, chickens (TANURE et al., 2015). In other words, the presence of animal species different from rats was a protection factor against leishmaniosis in rats $(\mathrm{OR}=0.01273$ to 0.8341$)$. A study on Nyssomyia neivai species broadly found in Paraná State (MEMBRIVE et al., 2004; DIAS-SVERSUTTI et al., 2007; SILVA et al., 2008; CERINO et al., 2009; CRUZ et al., 2013; MELO et al., 2013), performed in Ribeira Valley São Paulo State, examined 988 engorged females, and no rat blood was detected in the phlebotomines (MARASSÁ et al., 2013). According to Dias-Sversutti et al. (2007), N. neivai and N. whitmani are opportunists and probably adjust their feeding habits based on the availability of hosts.

$R$. rattus can be found in the domicile (BRANDÁO-FILHO et al., 2003; QUARESMA et al., 2011), in the peridomicile 
(BRANDÁO-FILHO et al., 2003; FERREIRA et al., 2015), in waste areas (VLADIMIR et al., 2015), in rural areas (ALEXANDER et al., 1998; BRANDĀO-FILHO et al., 2003; QUARESMA et al., 2011; FERREIRA et al., 2015), and in wild areas (RICHINI-PEREIRA et al., 2014; ZANET et al., 2014). Because of this adaptability, this rat species may be the link between sylvatic and peridomestic transmission cycles of leishmaniosis (BRANDÃO-FILHO et al., 2003; ANDRADE et al., 2015). We suggest that it may be the source of infection for peridomestic phlebotomine sand flies, specifically in cases of less anthropophilic vectors.

Despite difficulties, species-specific diagnosis is crucial to a better understanding of the complex network of transmission for Leishmania species (VAN DER AUWERA \& DUJARDIN, 2015). $R$. rattus has previously been found to be naturally infected with $L$. (L.) infantum, L. (L.) donovani, L. (L.) mexicana, and $L$. $(V$.) braziliensis in several places around the world such as Brazil (ALENCAR et al., 1960; BRANDÁO-FILHO et al., 2003; SVOBODOVÁ et al., 2003; OLIVEIRA et al., 2005; QUARESMA et al., 2011; LIMA et al., 2013) and other countries (LIMA et al., 2002; ZULUETA et al., 1999; DAVAMI et al., 2013; EL ADHAMI, 1976; IBRAHIM et al., 1992; POZIO et al., 1981; DI BELLA et al., 2003; ZANET et al., 2014; NAVEA-PÉREZ et al., 2015; VLADIMIR et al., 2015 and SINGH et al., 2013). As in this work, other studies have found rats captured in the same place with more than one Leishmania species: Lima et al. (2002) found $L$. (L.) mexicana and $L$. (V.) braziliensis, and Ferreira et al. (2015) found $L$. (L.) infantum and L. (V.) braziliensis; which is very interesting from an epidemiological point of view.

We found one animal naturally infected with $L$. (L.) infantum; however, North Paraná has not reported any authochnous cases of visceral leishmaniosis in dogs or humans caused by this agent. There have also not been any reports of its vector. We have three hypotheses to address this issue (from most to least likely): (i) railway lines pass by Londrina north region carrying grains, which may have brought infected rats from Sáo Paulo State; (ii) the vector is already endogenous to Londrina but new phlebotomine studies are needed to prove this; (iii) Londrina has a new vector that is transmitting $L$. (L.) infantum. In Paraná State, L. longipalpis was just discovered by Santos et al. (2012) in Foz do Iguaçu $(500 \mathrm{~km}$ from Londrina). According to D’Andrea et al. (2015), canine leishmaniosis is spreading fast from the western counties of São Paulo State (Presidente Prudente, $167 \mathrm{~km}$ from Londrina) toward the border of Parana State, and this is the most likely path to Londrina city to be followed by etiological agents and by the vector of visceral leishmaniosis.

This work is the first description of synanthropic rodents naturally infected by $L$. (L.) amazonensis in the world. This result corroborates an autochthonous case report of canine visceral leishmaniosis by L. (L.) amazonensis in Londrina published by our research group in 2012 (HOFFMANN et al., 2012) and an autochthonous case report of human cutaneous leishmaniosis by L. (L.) amazonensis in Maringá ( $80 \mathrm{~km}$ from Londrina) published in 1990 (SILVEIRA et al., 1990). Until the present work, this Leishmania species was only found naturally infecting wild rodents (LAINSON \& SHAW, 1968; LAINSON \& SHAW, 1970; CATARINO, 1998; TELLERIA et al., 1999). Clear expansion of leishmaniosis by L. (L.) amazonensis around the country has been observed over the last decades; according to Câmara-Coelho et al. (2011) 8\% of American cutaneous leishmaniosis cases in Brazil are caused by the above species. Several recent scientific studies describe this expansion; in terms of hosts, Souza et al. (2005), Dorval et al., (2010) and Cardoso et al. (2015) reported Felis catus domesticus (domestic cat), Mesocricetus auratus (hamster) and Necromys lasiurus (wild rodent) infection. In terms of geographical distribution, Dorval et al. (2006), Marlow et al. (2013) and Carvalho et al. (2013) reported its detection in Mato Grosso do Sul, Santa Catarina and Rio de Janeiro states, Brazil. Regarding clinical manifestations, Barral et al. (1991) and Oliveira et al. (2007), reported $L$. (L.) amazonensis causing visceral leishmaniosis in humans in Bahia and Maranhão, and Tolezano et al. (2007), Dias et al. (2011) and Hoffmann et al. (2012) reported L. (L.) amazonensis causing visceral leishmaniosis in dogs in São Paulo, Minas Gerais, and Paraná States.

The known phlebotomine sand fly vector species of L. (L.) amazonensis are L. flaviscutellata, L. reducta, and L. olmeca nociva (FREITAS et al., 1989; LAINSON \& SHAW, 1968; BRASIL, 2013). These vectors are less anthropophilic, which explains a lower frequency of human infection with this Leishmania species. Still corroborating with our hypothesis of L. (L.) amazonensis urbanization, Lu. flaviscutellata was found for the first time infected with it in a Brazilian urban area by Brilhante et al. (2015) in Bonito city, Mato Grosso do Sul state. A recent study (CARVALHO et al., 2014) using ecological niche modeling predicts southward expansion of L. flaviscutellata in South America because of climate change. Several studies have investigated phlebotomine fauna in Paraná State (GOMES \& GALATI, 1977; TEODORO et al., 1993; TEODORO et al., 1999; OLIVEIRA et al., 2000; DIAS-SVERSUTTI et al., 2007; SILVA et al., 2008; CERINO et al., 2009; REIS et al., 2011; CRUZ et al., 2012; SANTOS et al., 2012; MEMBRIVE et al., 2012; CRUZ et al., 2013; MELO et al., 2013); none reported $L$. (L.) amazonensis vectors. Taking into account two autochthonous cases (one human and one canine) of leishmaniasis by $L$. (L.) amazonensis in North Paraná, more studies about phlebotomine fauna must be made in this region, now using Disney traps with rodents as baits (DORVAL et al., 2007), because L. flaviscutellata is strongly attracted to rodents (LAINSON \& SHAW, 1968; SHAW \& LAINSON, 1972; CARVALHO et al., 2014).

\section{Conclusion}

This is the first description of synanthropic rodents naturally infected by $L$. (L.) amazonensis in the world, and by L. (L.) infantum in South Brazil. Regarding L. (L.) amazonensis, this finding is new evidence of the urbanization of this etiological agent, emphasizing the spread of leishmaniosis in Brazil and its neglected disease situation.

\section{Acknowledgements}

We are grateful to CAPES, CNPq and Fundação Araucária for financial support, to Thaís Gomes Verzignassi da Silveira for providing the DNA for the positive controls and to Mario 
Augusto Ono and Rafaela Macagnan for providing the serum for the positive controls.

\section{References}

Agência Nacional de Notícias do Paraná - ANP. Paraná registra primeiro caso de leishmaniose visceral em humanos [online]. Curitiba; 2015 [cited 2015 Jul 16]. Available from: http://www.aen.pr.gov.br/modules/noticias/ article.php? storyid $=84980$.

Akhavan AA, Mirhendi H, Khamesipour A, Alimohammadian MH, Rassi Y, Bates P, et al. Leishmania species: detection and identification by nested PCR assay from skin samples of rodent reservoirs. Exp Parasitol 2010; 126(4): 552-556. PMid:20566364. http://dx.doi.org/10.1016/j. exppara.2010.06.003.

Alencar JE, Pessoa EP, Fontenele ZF. Infecção natural de Rattus rattus alexandrinus por Leishmania (provavelmente L. braziliensis) em zona endêmica de leishmaniose tegumentar do Estado do Ceará. Brasil. Rev Inst Med Trop 1960; 2(6): 347-348.

Alexander B, Lozano C, Barker DC, McCann SHE, Adler GH. Detection of Leishmania (Viannia) braziliensis complex in wild mammals from Colombian coffee plantations by PCR and DNA hybridization. Acta Trop 1998; 69(1): 41-50. PMid:9588240. http://dx.doi.org/10.1016/ S0001-706X(97)00114-9.

Alvar J, Vélez ID, Bern C, Herrero M, Desjeux P, Cano J, et al. Leishmaniasis worldwide and global estimates of its incidence. PLoS One 2012; 7(5): e35671. PMid:22693548. http://dx.doi.org/10.1371/ journal.pone.0035671.

Andrade MS, Courtenay O, Brito ME, Carvalho FG, Carvalho AWS, Soares F, et al. Infectiousness of sylvatic and synanthropic small rodents implicates a multi-host reservoir of Leishmania (Viannia) braziliensis. PLoS Negl Trop Dis 2015; 9(10): e0004137. PMid:26448187. http:// dx.doi.org/10.1371/journal.pntd.0004137.

Ashford RW. Leishmaniasis reservoir and their significance in control. Clin Dermatol 1996; 14(5): 523-532. PMid:8889331. http://dx.doi. org/10.1016/0738-081X(96)00041-7.

Barbosa PBBM. Estudo sobre a participação de roedores na cadeia de transmissão de Leishmania infantum (Protozoa: Trypanosomatidae) no Rio Grande do Norte [Dissertação]. Rio Grande do Norte: Universidade Federal do Rio Grande do Norte; 2005.

Barral A, Pedral-Sampaio D, Grimaldi G Jr, Momen H, McMahon-Pratt D, Jesus AR, et al. Leishmaniasis in Bahia: evidence that Leishmania amazonensis produces a wide spectrum of clinical disease. Am J Trop Med Hyg 1991; 44(5): 536-546. PMid:2063957.

Ben-Ismail R, Khaled S, Makni S, Ben Rachid MS. Anti-leishmanial antibodies during natural infection of Psammomys obesus and Meriones shawi (Rodentia, Gerbillinae) by Leishmania major. Ann Soc Belg Med Trop 1989; 69(1): 35-40. PMid:2658879.

Bonvicino CR, Oliveira JA, D’Andrea OS. Guía dos roedores de Brasil: com chaves para gêneros baseadas em caracteres externos. Mastozool Neotrop 2008; 15(2): 374-379.

Brandão-Filho SP, Brito ME, Carvalho FG, Ishikawa EA, Cupolillo E, Floeter-Winter L, et al. Wild and synanthropic hosts of Leishmania (Viannia) braziliensis in the endemic cutaneous leishmaniasis locality of Amaraji, Pernambuco State, Brazil. Trans R Soc Trop Med Hyg 2003; 97(3): 291-296. PMid:15228244. http://dx.doi.org/10.1016/S00359203(03)90146-5.
Brasil. Ministério da Saúde. Manual de vigilância e controle da Leishmaniose Tegumentar Americana - MS. 2. ed. Brasília, DF: Ministério da Saúde; 2013.

Brasil. Ministério da Saúde. Manual de vigilância e controle da leishmaniose visceral. Brasília, DF: Ministério da Saúde; 2014.

Brilhante AF, Nunes VLB, Kohatsu KA, Galati EAB, Rocca MEG, Ishikawa EAY. Natural infection of phlebotomines (Diptera: Psychodidae) by Leishmania (Leishmania) amazonensis in an area of ecotourism in Central-Western Brazil. J Venom Anim Toxins Incl Trop Dis 2015; 21(1): 39. PMid:26435708. http://dx.doi.org/10.1186/s40409-015-0041-8.

Camara-Coelho LI, Paes M, Guerra JA, Barbosa MG, Coelho C, Lima B, et al. Characterization of Leishmania spp. causing cutaneous leishmaniasis in Manaus, Amazonas, Brazil. Parasitol Res 2011; 108(3): 671-677. PMid:21072540. http://dx.doi.org/10.1007/s00436-010-2139-9.

Cardoso RM, Araújo NNSL, Romero GAS, Souza TTCM, Dietrich AG, Mendes JD, et al. Expanding the knowledge about Leishmania species in wild mammals and dogs in the Brazilian savannah. Parasit Vectors 2015; 8(1): 171. PMid:25889365. http://dx.doi.org/10.1186/ s13071-015-0780-y.

Carvalho BM, Maximo M, Costa WA, Santana ALF, Costa SM, Costa Rego TAN, et al. Leishmaniosis transmission in an ecotourism area: potential vectors in Ilha Grande, Rio de Janeiro State, Brazil. Parasit Vectors 2013 6(1): 325. PMid:24499568. http://dx.doi.org/10.1186/1756-3305-6-325.

Carvalho BM, Rangel EF, Ready PD, Vale MM. Ecological niche modelling predicts southward expansion of Lutzomyia (Nyssomyia) flaviscutellata (Diptera: Psychodidae: Phlebotominae), vector of Leishmania (Leishmania) amazonensis in South America, under climate change. PLoS One 2014; 10(11): e0143282. PMid:26619186. http://dx.doi.org/10.1371/journal. pone. 0143282 .

Cássia-Pires R, Boité MC, D’Andrea PS, Herrera HM, Cupolillo E, Jansen AM, et al. Distinct Leishmania species infecting wild caviomorph rodents (Rodentia: Hystricognathi) from Brazil. PLoS Negl Trop Dis 2014; 8(12): e3389. PMid:25503973. http://dx.doi.org/10.1371/journal.pntd.0003389.

Castro EA, Thomaz-Soccol V, Augur C, Luz E. Leishmania (Viannia) braziliensis: epidemiology of canine cutaneous leishmaniasis in the State of Paraná (Brazil). Exp Parasitol 2007; 117(1): 13-21. PMid:17449032. http://dx.doi.org/10.1016/j.exppara.2007.03.003.

Catarino CLM. Leishmaniose tegumentar americana: uso de técnicas de biologia molecular no diagnóstico de infecção de roedores de coleção do Museu Nacional-UFRJ [Dissertação]. Rio de Janeiro: Fundação Oswaldo Cruz; Escola Nacional de Saúde Pública; 1998.

Cerino DA, Teodoro U, Silveira TGV. Sand flies (Diptera: Psychodidae) in the urban area of the municipality of Cianorte, Paraná state, Brazil. Neotrop Entomol 2009; 38(6): 853-858. PMid:20098934. http://dx.doi. org/10.1590/S1519-566X2009000600021.

Constantino C, Pasquali AKS, Caldart ET, Ferreira FP, Marana ERM, Freire RL, et al. Seroepidemiology of Leishmania spp. in dogs residing in Telêmaco Borba, Paraná, Brazil. Semina: Ciênc Agrár 2014; 35(6): 3181-3190.

Costa L, Caldart ET, Ruffolo BB, Toledo RS, Dias RCF, Navarro IT, et al. Leishmaniasis in dogs from recycling centers and from a neighborhood with adjacent forest in an urban area of Londrina, Paraná, Brazil. Semina: Ciênc Agrár 2016; 37(3): 1407-1414.

Cruz CFR, Cruz MFR, Galati EAB. Sandflies (Diptera: Psychodidae) in rural and urban environments in an endemic area of cutaneous leishmaniasis in southern Brazil. Mem Inst Oswaldo Cruz 2013; 108(3): 303-311. PMid:23778669. http://dx.doi.org/10.1590/S0074-02762013000300008. 
Cruz MFR, Galati EAB, Cruz CFR. Ecological aspects of the sandfly fauna (Diptera, Psychodidae) in an American cutaneous leishmaniasis endemic area under the influence of hydroelectric plants in Paranapanema river, State of Paraná, Brazil. Rev Soc Bras Med Trop 2012; 45(4): 430-436. PMid:22930040. http://dx.doi.org/10.1590/S0037-86822012000400003.

D'Andrea LAZ, Fonseca ES, Prestes-Carneiro LE, Guimarães RB, Yamashita RC, Soares CN, et al. The shadows of a ghost: a survey of canine leishmaniasis in Presidente Prudente and its spatial dispersion in the western region of São Paulo state, an emerging focus of visceral leishmaniasis in Brazil. BMC Vet Res 2015; 11(1): 273. PMid:26503368. http://dx.doi.org/10.1186/s12917-015-0583-6.

Dantas-Torres F, Paiva-Cavalcanti M, Figueredo LA, Melo MF, Silva FJ, Silva AL, et al. Cutaneous and visceral leishmaniasis in dogs from a rural community in northeastern Brazil. Vet Parasitol 2010; 170(3-4): 313317. PMid:20227186. http://dx.doi.org/10.1016/j.vetpar.2010.02.019.

Davami MH, Motazedian MH, Kalantari M, Asgari Q, Mohammadpour I, Sotoodeh-Jahromi A, et al. Molecular survey on detection of Leishmania infection in Rodent Reservoirs in Jahrom District, Southern Iran. $J$ Arthropod Borne Dis 2013; 8(2): 139-146. PMid:26114127.

Dean AG, Dean JA, Burton AH, Dicker RC. Epi Info: a general-purpose microcomputer program for public health information systems. Am J Prev Med 1990; 7(3): 178-182. PMid:1657068.

Di Bella C, Vitale F, Russo G, Greco A, Milazzo C, Aloise G, et al. Are rodents a potential reservoir for Leishmania infantum in Italy? J Mountain Ecol 2003; 7: 125-129.

Dias ES, Regina-Silva S, França-Silva JC, Paz GF, Michalsky EM, Araújo SC, et al. Eco-epidemiology of visceral leishmaniasis in the urban area of Paracatu, state of Minas Gerais, Brazil. Vet Parasitol 2011; 176(2): 101111. PMid:21146311. http://dx.doi.org/10.1016/j.vetpar.2010.11.014.

Dias-Sversutti ADC, Scodro RBL, Reinhold-Castro KR, Neitzke HC, Teodoro U. Preliminary study on feeding preference of Nyssomyia neivai (Pinto) and Nyssomyia whitmani (Antunes \& Coutinho) (Diptera: Psychodidae) in a rural area of the state of Paraná, South Brazil. Neotrop Entomol 2007; 36(6): 953-959. PMid:18246272. http://dx.doi.org/10.1590/ S1519-566X2007000600019.

Díaz-Sáez V, Merino-Espinosa G, Morales-Yuste M, Corpas-López V, Pratlong F, Morillas-Márquez F, et al. High rates of Leishmania infantum and Trypanosoma nabiasi infection in wild rabbits (Oryctolagus cuniculus) in sympatric and syntrophic conditions in an endemic canine leishmaniasis area: Epidemiological consequences. Vet Parasitol 2014; 202(3-4): 119127. PMid:24774436. http://dx.doi.org/10.1016/j.vetpar.2014.03.029.

Dorval MEC, Alves TP, Cristaldo G, Rocha HC, Alves MA, Oshiro ET, et al. Sand fly captures with Disney traps in area of occurrence of Leishmania (Leishmania) amazonensis in the State of Mato Grosso do Sul, mid-western Brazil. Rev Soc Bras Med Trop 2010; 43(5): 491-495. PMid:21085855. http://dx.doi.org/10.1590/S0037-86822010000500003.

Dorval MEC, Alves TP, Oliveira AG, Brazil RP, Galati EAB, Cunha RV. Modification of Disney trap for capture of sand flies (Diptera: Psychodidae: Phlebotominae). Mem Inst Oswaldo Cruz 2007; 102(7): 877-878. PMid:17992367. http://dx.doi.org/10.1590/S0074-02762007005000111.

Dorval MEMC, Oshiro ET, Cupollilo E, Castro ACC, Alves TP. Occurrence of American tegumentary leishmaniasis in the Mato Grosso do Sul State associated to the infection for Leishmania (Leishmania) amazonensis. Rev Soc Bras Med Trop 2006; 39(1): 43-46. PMid:16501765. http://dx.doi. org/10.1590/S0037-86822006000100008.

Dujardin JC, Campino L, Cañavate C, Dedet JP, Gradoni L, Soteriadou $\mathrm{K}$, et al. Spread of vector-borne diseases and neglect of leishmaniasis,
Europe. Emerg Infect Dis 2008; 14(7): 1013-1018. PMid:18598618. http://dx.doi.org/10.3201/eid1407.071589.

El Adhami B. Isolation of Leishmania from a black rat in the Baghdad area, Iraq. Am J Trop Med Hyg 1976; 25(5): 759-761. PMid:962001.

Empresa Brasileira de Pesquisa Agropecuária-EMBRAPA. Electropherogram quality analysis [online]. Londrina; 2016 [cited 2015 Sept 19]. Avaliable from: http://asparagin.cenargen.embrapa.br/phph

Ferreira EC, Cruz I, Cañavate C, Melo LA, Pereira AA, Madeira FA, et al. Mixed infection of Leishmania infantum and Leishmania braziliensis in rodents from endemic urban area of the New World. BMC Vet Res 2015; 11(1): 71. PMid:25890323. http://dx.doi.org/10.1186/s12917-015-0392-y.

Forattini OP. Entomologia médica. São Paulo: Editora Edgard Blücher; 1973.

Freitas RA, Barrett TV, Naiff RD. 1988, a host of Leishmania amazonensis, sympatric with two other members of the Flaviscutellata complex in southern Amazonas and Rondonia, Brazil (Diptera: Psychodidae). Mem Inst Oswaldo Cruz 1989; 84(3): 363-369. http://dx.doi.org/10.1590/ S0074-02761989000300011.

Fundação Nacional de Saúde - FUNASA. Manual de controle de roedores. Brasília, DF; 2002.

Gomes AC, Galati EAB. Flebotomíneos de Londrina, Paraná (Brasil) e observaçôes ecológicas sobre algumas espécies. Rev Saude Publica 1977; 11(2): 284-287. PMid:905753. http://dx.doi.org/10.1590/S003489101977000200013 .

Gramiccia M. Recent advances in leishmaniosis in pet animals: epidemiology, diagnostics and anti-vectorial prophylaxis. Vet Parasitol 2011; 181(1): 2330. PMid:21570192. http://dx.doi.org/10.1016/j.vetpar.2011.04.019.

Helhazar M, Leitão J, Duarte A, Tavares L, Fonseca IP. Natural infection of synathropic rodent species Mus musculus and Rattus norvegicus by Leishmania infantum in Sesimbra and Sintra - Portugal. Parasit Vectors 2013; 6(1): 88. PMid:23566789. http://dx.doi.org/10.1186/1756-3305-6-88.

Hoffmann AR, Navarro IT, Camargo-Jr VE, Caldart ET, Mitsuka-Breganó R, Pereira PM. Leishmania amazonensis em cão com quadro clínico de leishmaniose visceral no Estado do Paraná, Brasil - relato de caso. Semina: Ciênc Agrar 2012; 33(6): 3265-3270.

Ibrahim EA, Al-Zahrani MA, Al-Tuwaigri AS, Al-Shammary FJ, Evans DA. Leishmania infecting man and wild animals in Saudi Arabia. 9. The black rat (Rattus rattus) a probable reservoir of visceral Leishmaniasis in Gizan province, south-west Saudi Arabia. Trans R Soc Trop Med Hyg 1992; 86(5): 513-514. PMid:1475818. http://dx.doi.org/10.1016/00359203(92)90090-Y.

Instituto Brasileiro de Geografia e Estatística - IBGE. [online]. Rio de Janeiro; 2015 [cited 2015 Jul 16]. Available from: http://cidades.ibge. gov.br/xtras/perfil.php? $\operatorname{codmun}=411370$

Instituto de Pesquisa e Planejamento Urbano de Londrina - IPPUL. [online]. Londrina; 2008 [cited 2016 nov 23]. Avaliable from: http://www1.londrina.pr.gov.br/dados/images/stories/Storage/ippul/ apresentacao_produto_04.pps

Lainson R, Shaw JJ. Leishmaniasis in Brazil: I. Observations on enzootic rodent leishmaniasis-incrimination of Lutzomyia flaviscutellata (Mangabeira) as the vector in the lower Amazonian Basin. Trans R Soc Trop Med Hyg 1968; 62(3): 385-395. PMid:5659232. http://dx.doi.org/10.1016/00359203(68)90090-4.

Lainson R, Shaw JJ. Leishmaniasis in Brazil: V. Studies on the epidemiology of cutaneous leishmaniasis in Mato Grosso State, and observations on two distinct strains of Leishmania isolated from man and forest animals. 
Trans R Soc Trop Med Hyg 1970; 64(5): 654-667. PMid:5500537. http:// dx.doi.org/10.1016/0035-9203(70)90002-7.

Lara-Silva FO, Barata RA, Michalsky EM, Ferreira EC, Lopes MOG, Pinheiro AC, et al. Rattus norvegicus (Rodentia: Muridae) Infected by Leishmania (Leishmania) infantum (syn. Le. chagasi) in Brazil. BioMed Res Int 2014; 2014: 592986. PMid:24707492. http://dx.doi. org/10.1155/2014/592986.

Lima BS, Dantas-Torres F, Carvalho MR, Marinho-Junior JF, Almeida EL, Brito ME, et al. Small mammals as hosts of Leishmania spp. in a highly endemic area for zoonotic leishmaniasis in north-eastern Brazil. Trans R Soc Trop Med Hyg 2013; 107(9): 592-597. PMid:23868744. http://dx.doi.org/10.1093/trstmh/trt062.

Lima H, Guglielmo Z, Rodríguez A, Convit J, Rodriguez N. Cotton rats (Sigmodon hispidus) and black rats (Rattus rattus) as possible reservoirs of Leishmania spp. in Lara State, Venezuela. Mem Inst Oswaldo Cruz 2002; 97(2): 169-174. PMid:12016437. http://dx.doi.org/10.1590/ S0074-02762002000200004.

Marassá AM, Galati EAB, Bergamaschi DP, Consales CA. Blood feeding patterns of Nyssomyia intermedia and Nyssomyia neivai (Diptera, Psychodidae) in a cutaneous leishmaniasis endemic area of the Ribeira Valley, State of São Paulo, Brazil. Rev Soc Bras Med Trop 2013; 46(5): 547-554. PMid:24270245. http://dx.doi.org/10.1590/0037-8682-0168-2013.

Marcelino AP, Ferreira EC, Avendanha JS, Costa CF, Chiarelli D, Almeida $\mathrm{G}$, et al. Molecular detection of Leishmania braziliensis in Rattus norvegicus in an area endemic for cutaneous leishmaniasis in Brazil. Vet Parasitol 2011; 183(1-2): 54-58. PMid:21767914. http://dx.doi.org/10.1016/j. vetpar.2011.06.019.

Marlow MA, Mattos MS, Makowiecky ME, Eger I, Rosseto AL, Grisard EC, et al. Divergent Profile of emerging cutaneous Leishmaniosis in Subtropical Brazil: new endemic areas in the Southern frontier. PLoS One 2013; 8(2): e56177. PMid:23457521. http://dx.doi.org/10.1371/ journal.pone.0056177.

Melo SCCS, Cella W, Massafera R, Silva NMMG, Marqui R, Carvalho $\mathrm{MDB}$, et al. Phlebotomine sandflies in rural locations in the State of Parana, southern Brazil. Rev Inst Med Trop 2013; 55(6): 407-410. PMid:24213193. http://dx.doi.org/10.1590/S0036-46652013000600006.

Membrive NA, Rodrigues G, Gualda KP, Bernal MVZ, Oliveira DM, Lonardoni MVC, et al. Environmental and animal characteristics as factors associated with American cutaneous leishmaniasis in rural locations with presence of dogs, Brazil. PLoS One 2012; 7(11): e47050. PMid:23144799. http://dx.doi.org/10.1371/journal.pone.0047050.

Membrive NA, Rodrigues G, Membrive U, Monteiro WM, Neitzke HC, Lonardoni MVC, et al. Flebotomíneos de municípios do norte do estado do Paraná, sul do Brasil. Entomol Vectores 2004; 11(4): 673-680. http://dx.doi.org/10.1590/S0328-03812004000400009.

Mendonça PG, Harsch A, Mogl C, Walther B, Boje J, Dimke C. Molecular Screening of wild rodents for Leishmania infantum in Germany. Acta Zool Bulg 2011; 63(3): 307-311.

Mimori T, Sasaki J, Nakata M, Gomez EA, Uezato H, Nonaka S, et al. Rapid identification of Leishmania species from formalin-fixed biopsy samples by polymorphism-specific polymerase chain reaction. Gene 1998; 210(2): 179-186. PMid:9573358. http://dx.doi.org/10.1016/ S0378-1119(97)00663-X.

Mirzaei A, Schweynoch C, Rouhani S, Parvizi P, Schönian G. Diversity of Leishmania species and of strains of Leishmania major isolated from desert rodents in different foci of cutaneous leishmaniasis in Iran. Trans
R Soc Trop Med Hyg 2014; 108(8): 502-512. PMid:24980555. http:// dx.doi.org/10.1093/trstmh/tru085.

Mukhtar MM, Sharief AH, El Saffi SH, Harith AE, Higazzi TB, Adam AM, et al. Detection of antibodies to Leishmania donovani in animals in a kala-azar endemic region in eastern Sudan: a preliminary report. Trans $R$ Soc Trop Med Hyg 2000; 94(1): 33-36. PMid:10748894. http://dx.doi. org/10.1016/S0035-9203(00)90429-2.

Navea-Pérez HM, Díaz-Sáez V, Corpas-López V, Merino-Espinosa G, Morillas-Márquez F, Martín-Sánchez J. Leishmania infantum in wild rodents: reservoirs or just irrelevant incidental hosts? Parasitol Res 2015 114(6): 2363-2370. PMid:25797596. http://dx.doi.org/10.1007/ s00436-015-4434-y.

National Center for Biotechnology Information - NCBI. Basic Local Alignment Search Tool - BLAST [online]. Londrina; 2016 [cited 2015 Sept 19]. Avaliable from: https://blast.ncbi.nlm.nih.gov/Blast.cgi

Negrão GN, Ferreira MEMC. Consideraçôes sobre a dispersão da leishmaniose tegumentar americana nas Américas. Rev Percurso 2009; 1(1): 85-103

Neitzke-Abreu HC, Venazzi MS, Bernal MVZ, Reinhold-Castro KR, Vagetti F, Mota CA, et al. Detection of DNA from Leishmania (Viannia): Accuracy of polymerase chain reaction for the diagnosis of cutaneous Leishmaniasis. PLoS One 2013; 8(7): e62473. PMid:23976920. http:// dx.doi.org/10.1371/journal.pone.0062473.

Oliveira FJA, Costa IC, Thomaz MEB, Nunes V, Oliveira O, OliveiraNeto BP, et al. Leishmaniose Tegumentar Americana: flebotomíneos de área de transmissão do Parque Arthur Thomas na região de Londrina - PR. Biosaúde 2000; 2(1): 81-87.

Oliveira FS, Pirmez C, Pires MQ, Brazil RP, Pacheco RS. PCR-based diagnosis for detection of Leishmania in skin and blood of rodents from an endemic area of cutaneous and visceral leishmaniasis in Brazil. Vet Parasitol 2005; 129(3-4): 219-227. PMid:15845276. http://dx.doi. org/10.1016/j.vetpar.2005.01.005.

Oliveira JPC, Fernandes F, Cruz AK, Trombela V, Monteiro E, Camargo AA, et al. Genetic diversity of Leishmania amazonensis strains isolated in northeastern Brazil as revealed by DNA sequencing, PCR-based analyses and molecular karyotyping. Kinetop Biol Dis 2007; 6: 5. PMid:17584940.

Oliveira TMFS, Furuta PI, Carvalho D, Machado RZ. A study of crossreactivity in serum samples from dogs positive for Leishmania sp., Babesia canis and Ehrlichia canis in enzyme-linked immunosorbent assay and indirect fluorescent antibody test. Rev Bras Parasitol Vet 2008; 17(1) 7-11. PMid:18554433.

Papadogiannakis E, Spanakos G, Kontos V, Menounos PG, Tegos N, Vakalis N. Molecular detection of Leishmania infantum in wild rodents (Rattus norvegicus) in Greece. Zoonoses Public Health 2010; 57(7-8): e23-e25. PMid:19912600. http://dx.doi.org/10.1111/j.1863-2378.2009.01264.x.

Pontello R Jr, Gon AS, Ogama A. American cutaneous leishmaniasis: epidemiological profile of patients treated in Londrina from 1998 to 2009. An Bras Dermatol 2013; 88(5): 748-753. PMid:24173180. http:// dx.doi.org/10.1590/abd1806-4841.20132168.

Pozio E, Gradoni L, Bettini S, Gramiccia M. Leishmaniasis in Tuscany (Italy) V. Further isolation of Leishmania from Rattus rattus in the province of Grosseto. Ann Trop Med Parasitol 1981; 75(4): 393-395. PMid:7305507. http://dx.doi.org/10.1080/00034983.1981.11687457.

Quaresma PF, Rêgo FD, Botelho HA, Silva SR, Moura AJ Jr, Teixeira RG No, et al. Wild, synanthropic and domestic hosts of Leishmania in an endemic area of cutaneous leishmaniasis in Minas Gerais State, Brazil. 
Trans R Soc Trop Med Hyg 2011; 105(10): 579-585. PMid:21890159. http://dx.doi.org/10.1016/j.trstmh.2011.07.005.

Reis HR, Lopes-Mori FMR, Reis CR, Freire RL, Marana ERM, Chryssafidis $\mathrm{AL}$, et al. Soroprevalência da leishmaniose tegumentar americana (LTA) canina e fauna de flebotomíneos (Diptera: Psychodidae) em Bela Vista do Paraíso, Paraná. Semina: Cienc Agrár 2011; 32(3): 1083-1094.

Richini-Pereira VB, Marson PM, Hayasaka EY, Victoria C, Silva RC, Langoni H. Molecular detection of Leishmania spp. in road-killed wild mammals in the Central Western area of the State of São Paulo, Brazil. J Venomous Anim Toxins Trop Dis 2014; 20(1): 27. PMid:24963288. http://dx.doi.org/10.1186/1678-9199-20-27.

Roque ALR, Jansen AM. Wild and synanthropic reservoirs of Leishmania species in the Americas. Int J Parasitol Parasites Wildl 2014; 3(3): 251262. PMid:25426421. http://dx.doi.org/10.1016/j.ijppaw.2014.08.004.

Rotureau B. Ecology of the Leishmania species in the Guianan ecoregion complex. Am J Trop Med Hyg 2006; 74(1): 81-96. PMid:16407350.

Santos DR, Ferreira AC, Bisetto A Jr. O primeiro registro de Lutzomyia longipalpis (Lutz \& Neiva, 1912) (Diptera: Psychodidae), no Estado do Paraná, Brasil. Rev Soc Bras Med Trop 2012; 45(5): 643-645. PMid:23152351. http://dx.doi.org/10.1590/S0037-86822012000500019.

Shaw JJ, Lainson R. Leishmaniasis in Brazil: VI. Observations on the seasonal variations of Lutzomyia flaviscutellata in different types of forest and its relationship to enzootic rodent leishmaniasis (Leishmania mexicana amazonensis). Trans R Soc Trop Med Hyg 1972; 66(5): 709-717. PMid:4647642. http://dx.doi.org/10.1016/0035-9203(72)90084-3.

Shender LA, de los Santos M, Montgomery JM, Conrad PA, Ghersi BM, Razuri H, et al. Native Rodent species are unlikely sources of infection for Leishmania (Viannia) braziliensis along the transoceanic highway in Madre de Dios, Peru. PLoS One 2014; 9(7): e103358. PMid:25062033. http://dx.doi.org/10.1371/journal.pone.0103358.

Silva AM, Camargo NJ, Santos DR, Massafera R, Ferreira AC, Postai C, et al. Diversidade, distribuição e abundância de flebotomíneos (Diptera: Psychodidae) no Paraná. Neotrop Entomol 2008; 37(2): 209-225. PMid:18506303. http://dx.doi.org/10.1590/S1519-566X2008000200017.

Silveira TGV, Teodoro U, Arraes SMAA, Lonardoni MVC, Dias MLGG, Shaw JJ, et al. An Autochthonous case of cutaneous leishmaniasis caused by Leishmania (Leishmania) amazonensis Laison \& Shaw, 1972 from the North of Paraná State, Brazil. Mem Inst Oswaldo Cruz 1990; 85(1): 475-476. PMid:2152201. http://dx.doi.org/10.1590/S0074-02761990000400014.

Singh N, Mishra J, Singh R, Singh S. Animal reservoirs of visceral leishmaniasis in India. J Parasitol 2013; 99(1): 64-67. PMid:22765517. http://dx.doi.org/10.1645/GE-3085.1.

Sistema de Informação de Agravos de Notificaçâo - SINAN. [online]. Brasília, DF; 2016 [cited 2016 Nov 23]. Available from: http://www2. datasus.gov.br/DATASUS/index.php?area=0203\&id=29878153

Souza AL, Barros EMS, Ishikawa E, Ilha IMN, Marin GRB, Nunes VLB. Feline leishmaniasis due to Leishmania (Leishmania) amazonensis in Mato Grosso do Sul State, Brazil. Vet Parasitol 2005; 128(1-2): 4145. PMid:15725531. http://dx.doi.org/10.1016/j.vetpar.2004.11.020.

Svobodová M, Votýpka J, Nicolas L, Volf P. Leishmania tropica in the black rat (Rattus rattus): persistence and transmission from asymptomatic host to sand fly vector Phlebotomus sergenti. Microbes Infect 2003; 5(5): 361-364. PMid:12737990. http://dx.doi.org/10.1016/S1286-4579(03)00046-7.

Szargiki R. Comparação de Métodos diagnósticos em leishmaniose tegumentar Americana [Dissertação]. Curitiba: Universidade Federal do Paraná; 2005.

Tanure A, Peixoto JC, Afonso MMS, Duarte R, Pinheiro AC, Coelho SVB, et al. Identification of sandflies (Diptera: Psychodidae: Phlebotominae) blood meals in an endemic leishmaniasis area in Brazil. Rev Inst Med Trop 2015; 57(4): 321-324. PMid:26422156. http://dx.doi.org/10.1590/ S0036-46652015000400008.

Telleria J, Bosseno MF, Tarifa T, Buitrago R, Martinez E, Torrez M, et al. Putative reservoirs of Leishmania amazonensis in a Sub-Andean focus of Bolivia identified by kDNA-polymerase chain reaction. Mem Inst Oswaldo Cruz 1999; 94(1): 5-6. PMid:10029903. http://dx.doi.org/10.1590/ S0074-02761999000100002.

Teodoro U, Balduíno J, Thomaz-Soccol V, Barbosa OC, Ferreira MEMC, Lozovei AL, et al. Environmental sanitation and peri-domiciliar organisation as auxiliary practices for the control of phlebotomines in Paraná state, southern Brazil. Braz Arch Biol Technol 1999; 42(3): 307-314.

Teodoro U, La Salvia V Fo, Lima EM, Spinosa RP, Barbosa OC, Ferreira MEMC, et al. Flebotomíneos em área de transmissão de leishmaniose tegumentar na região norte do Estado do Paraná - Brasil: variação sazonal e atividade noturna. Rev Saude Publica 1993; 27(3): 190-194. PMid:8115833. http://dx.doi.org/10.1590/S0034-89101993000300006.

Tolezano JE, Uliana SR, Taniguchi HH, Araújo MF, Barbosa JA, Barbosa JE, et al. The first records of Leishmania (Leishmania) amazonensis in dogs (Canis familiaris) diagnosed clinically as having canine visceral leishmaniasis from Araçatuba County, São Paulo State, Brazil. Vet Parasitol 2007; 149(3-4): 280-284. PMid:17720321. http://dx.doi.org/10.1016/j. vetpar.2007.07.008.

Van der Auwera G, Dujardin JC. Species typing in dermal Leishmaniasis. Clin Microbiol Rev 2015; 28(2): 265-294. PMid:25672782. http://dx.doi. org/10.1128/CMR.00104-14.

Van Eys GJJM, Schoone GJ, Kroon NC, Ebeling SB. Sequence analysis of small subunit ribosomal RNA genes and its use for detection and identification of Leishmania parasites. Mol Biochem Parasitol 1992; 51(1): 133-142. PMid:1565128. http://dx.doi.org/10.1016/01666851(92)90208-2.

Vladimir I, Katja K, Sara Z, Elena B. Illegal waste sites as a potential micro foci of mediterranean Leishmaniasis: first records of Phlebotomine Sand Flies (Diptera: Psychodidae) from Slovenia. Acta Vet (Beogr) 2015; 65(3): 348-357. http://dx.doi.org/10.1515/acve-2015-0029.

Zanet S, Sposimo P, Trisciuoglio A, Giannini F, Strumia F, Ferroglio E. Epidemiology of Leishmania infantum, Toxoplasma gondii, and Neospora caninum in Rattus rattus in absence of domestic reservoir and definitive hosts. Vet Parasitol 2014; 199(3-4): 247-249. PMid:24295953. http:// dx.doi.org/10.1016/j.vetpar.2013.10.023.

Zulueta AM, Villarroel E, Rodriguez N, Feliciangeli MD, Mazzarri M, Reyes $\mathrm{O}$, et al. Epidemiologic aspects of American visceral leishmaniosis in endemic focus in eastern Venezuela. Am J Trop Med Hyg 1999; 61(6): 945-950. PMid:10674675. 